\title{
PENGARUH LINGKUNGAN FISIK LINGKUNGAN SEKOLAH DAN DUKUNGAN SOSIAL KELUARGA TERHADAP PERILAKU ANAK AUTIS DI KOTA PEKANBARU
}

\author{
Risda Selvia Saragih, Zulkarnaini, Riki Sukiandra
}

\begin{abstract}
Alumni Pascasarjana Ilmu Lingkungan Program Pascasarjana Universitas Riau, Pekanbaru Dosen Pascasarjana Ilmu Lingkungan Program Pascasarjana Universitas Riau, Pekanbaru Jl. Pattimura No.09.Gobah, 28131. Telp 0761-23742.
\end{abstract}

e-mail:risda_srgh@yahoo.com

\begin{abstract}
ABSTRAK
Tujuan dari penelitian ini adalah untuk menganalisis lingkungan fisik, lingkungan sekolah dan dukungan sosial keluarga terhadap perilaku anak autis. Lokasi penelitian dilaksanakan di Yayasan Sekolah Pelatihan Terapi Anak Mandiri dan Yayasan Special Kids Pekanbaru. Metode penelitian yang digunakan adalah survey terhadap perilaku anak autis. Hasil dari penelitian ini adalah Lingkungan fisik memberikan pengaruh yang bermakna terhadap perilaku anak autis seperti suara handphone, suara hairdryer dan suara lalu lintas dengan stimulus anak melompat-lompat, berlari-lari tanpa tujuan, suka berteriak dan tidak dapat duduk lama. Serta cahaya diruang gelap dan cahaya matahari juga memberikan pengaruh yang bermakna terhadap perilaku anak autis dengan stimulus anak melompat-lompat dan berjalan tanpa tujuan dan ada pengaruh suara dan cahaya terhadap sebagian besar anak sehingga cenderung berperilaku defisit. Pada lingkungan sekolah memberikan pengaruh yang bermakna terhadap perilaku anak autis, Artinya semakin sering guru sekolah memberikan dukungan dan arahan informatif kepada anak, maka anak semakin dapat berperilaku hiperaktif dengan cara belajar disekolah seperti berolahraga, cara mengucapkan salam kepada teman dan berinteraksi yang baik kepada lingkungan disekitarnya. Kemudian hasil penelitian menunjukan terdapat pengaruh yang bermakna antara dukungan sosial keluarga terhadap perilaku anak autis. Dukungan sosial keluarga yang rendah terhadap perilaku anak yang kebanyakan hiperaktif, sedangkan anak yang kategori defisit hanya sebagian kecil dukungan sosial keluarganya yang tinggi.
\end{abstract}

Kata Kunci: Perilaku Anak Autis, Lingkungan Fisik Lingkungan Sekolah dan Dukungan Sosial Keluarga

\section{PENDAHULUAN}

Keluarga merupakan ujung tombak pendidikan anak yang pertama dan utama, yang berperan penting dalam mendidik dan membimbing serta memiliki tanggung jawab dalam memberikan pendidikan bagi anakanaknya. Pendidikan diberikan tidak hanya untuk anak yang normal melainkan juga kepada anak yang memiliki kebutuhan khusus yang sering dikenal sebagai "special kids", salah satunya adalah anak yang mengalami autis (Soendari, 2008).

Jumlah anak penyandang autis dari tahun ke tahun yang semakin meningkat, menuntut orangtua untuk lebih perduli dan ikut mengambil alih peran dalam kemajuan perkembangan anak. Banyak orangtua yang menyerahkan sepenuhnya pendidikan dan kebutuhan anak ke sekolah dan pembantunya dikarenakan kesibukan bekerja dan lainnya. Keluarga kurang mengetahui perkembangan perilaku anak mengarah ke hiperaktif atau defisit. Orangtua atau keluarga tidak menyadari kalau dukungan lingkungan fisik, lingkungan sekolah dan sosial keluarga sekitar anak sangat berpengaruh terhadap perkembangan perilaku (Marijani, 2003).

Autisme atau yang biasa disebut dengan autis adalah suatu kondisi seorang anak yang sejak lahir atau pada saat masih anak-anak, yang membuat dirinya tidak dapat membentuk hubungan sosial atau komunikasi yang normal dengan lingkungan sekitarnya. Perilaku hiperaktif ditandai dengan gerakan aktif yang ditimbulkan oleh anak dan gerakan tersebut tidak memiliki tujuan yang jelas seperti melompat - lompat, berjalan mondar mandir tanpa tujuan, berlari-lari, dan tidak dapat duduk tenang dalam waktu lama. Perilaku hiperaktif yang terus menerus menyebabkan anak tidak dapat menerima stimulus dengan baik saat belajar, sulitnya anak untuk 
beradaptasi dengan lingkungan karena gerakan yang berlebihan yang berakibat kurangnya pemahan orang lain dan lingkungan sulit menerima keadaan anak autis. Perilaku defisit kebalikan dari perilaku hiperaktif, ditandai anak dengan cenderung duduk diam, suka menangis, tidak mau diajak bermain, mendengarkan suara selalu menutup kuping dan tidak perduli dengan aktivitas yang ada di lingkungan sekitarnya. Hal ini tentunya menimbulkan dampak yang tidak baik terhadap perkembangan anak autis kedepan. Anak yang menderita autis memiliki gangguan perkembangan yang kompleks (Soendari, 2008).

Penderita autis di Indonesia setiap tahunnya terus mengalami peningkatan. Departemen Kesehatan RI menyebutkan bahwa jumlah penderita autis di Indonesia di tahun 2007 tercatat sebanyak 485 ribu penderita dan sekarang diperkirakan setiap 1 dari 150 anak yang lahir menderita autisme. Hadis (2006), mengatakan jumlah anak di Indonesia yang mengalami autis diperkirakan ada sekitar 517.017 anak sampai dengan 1.292.542 anak dari 25.850.849 keseluruhan populasi anak di Indonesia. Di Indonesia tahun 1990 an jumlah anak yang terdiagnosis autis setiap tahunnya sekitar mencapai 6 orang atau lebih. Tahun 2010 meningkat pesat sekitar 2,4 juta dan bertambah sekitar 500 orang setiap tahunnya. Peningkatan penderita autis juga terjadi Provinsi Riau, menurut Purwanto (2009), penderita autis terus mengalami peningkatan berdasarkan data yang diungkapkan wakil ketua II Forum Pengembangan Anak Penyandang Autis (FPAPA) pada tahun 2012 penderita autis mencapai 820 anak. Dari beberapa pusat terapi autis yang ada dipekanbaru, seperti Yayasan Sekolah Pelatihan Terapi Anak Mandiri dan Yayasan Special Kids didapatkan jumlah anak autis mengalami peningkatan dari tahun ke tahun. Perbandingan anak lakilaki dan perempuan penyandang autis adalah empat banding satu.

Berdasarkan hasil penelitian ke Yayasan Sekolah Pelatihan Terapi anak Mandiri dan wawancara dengan guru di sekolah, penanganan yang dilakukan oleh guru di sekolah khusus terapi anak mandiri terdapat masalah gangguan interaksi sosial anak autis adalah menggunakan penanganan dini dengan melatih pemberian salam pada awal pembelajaran, berjalan-jalan di sekeliling lingkungan luar, senam, makan, bermain bersama, kegiatan berenang, terapi musik, dan kegiatan lain yang lebih kompleks. Selain itu di luar dari sekolah anak-anak dijemput oleh pengasuhnya dan orang tua juga jarang berkomunikasi atau berinteraksi langsung kepada guru untuk mengetahui perkembangan anaknya baik itu komunikasi langsung maupun komunikasi lewat media buku komunikasi. Berdasarkan wawancara dengan guru atau terafisnya jika anak masuk sekolah setelah libur, prilaku anak menjadi aktif dan sulit dikendalikan, anak yang biasanya sudah dapat beradaptasi dengan suara kembali ketakutan saat mendengar suara handphone dan suara yang keras. Guru atau terafis anak berusaha untuk mengajak anak bermain keluar dan mengajak anak diruangan yang cahayanya lebih terang namun kebanyakan anak menolak dan lebih senang berada di dalam ruangan yang tertutup.

Berdasarkan fenomena uraian di atas peneliti tertarik untuk meneliti tentang pengaruh dukungan lingkungan fisik, lingkungan sekolah dan dukungan sosial keluarga terhadap prilaku anak autis dikota pekanbaru.

\section{METODOLOGI PENELITIAN}

Kegiatan penelitian telah dilaksanakan dari 3 November 2015 sampai dengan 25 April 2016 di Yayasan Sekolah Pelatihan Terapi Anak Mandiri Jl. Kutilang No. 5 Sukajadi Pekanbaru, dan Yayasan Special Kids Jl. Taman Sari No.47 Tangkerang Pekanbaru. Pemilihan kedua sekolah tersebut karena Yayasan sekolah ini memiliki banyak anak autis berada pada tahap perkembangan anak usia sekolah.

Metode yang digunakan dalam penelitian ini adalah metode survey. Teknik pengambilan sampel yang digunakan dalam 
penelitian ini adalah purposive sampling. Adapun kriteria yang menjadi sampelnya adalah anak autis yang bersekolah di Yayasan Sekolah Pelatihan

Terapi Anak Mandiri, dan Yayasan Special Kids Pekanbaru, Keluarga yang mempunyai anak penyandang autis usia 7 tahun sanpai dengan 13 tahun (berada pada tahap perkembangan anak usia sekolah) dan bersedia untuk menjadi responden dalam penelitian ini. Data yang diperoleh dianalisis secara deskripstif dengan tabel, selain itu juga dilakukan Uji Statistik dengan Uji chi-square untuk melihat pengaruh antara lingkungan fisik, lingkungan sekolah dan dukungan sosial keluarga terhadap perilaku anak autis dikota pekanbaru.

\section{HASIL DAN PEMBAHASAN}

Lokasi penelitian ini adalah Yayasan Sekolah Pelatihan Terapi Anak Mandiri terletak di Jl. Kutilang No. 5 Sukajadi Pekanbaru, sekolah yayasan ini memiliki jumlah guru sebanyak 20 dan 30 anak autis. Yayasan ini memiliki tempat terapi bagi anak autis. Pendidikan anak rata-rata yang bersekolah mecapai 1 - 3 tahun.

Yayasan Special Kids terletak di Jl. Taman Sari No.47 Tangkerang Pekanbaru. Yayasan ini memiliki 30 anak autis dan 20 guru pengajar, yayasan ini menerima terapi bagi anak autis dan yayasan ini menerima semua anak yang berkebutuhan khusus serta tidak membatasi jumlah anak. Rata-rata pendidikan sekolah anak mencapai 1-3 tahun.

Karakteristik Variabel pengaruh lingkungan fisik lingkungan sekolah dan dukungan sosial keluarga terhadap perilaku anak autis, adapun Variabel lingkungan fisik terhadap perilaku anak autis (Tabel 1).

Tabel 1. Deskripsi variabel lingkungan fisik terhadap perilaku anak autis

\begin{tabular}{|c|c|c|c|c|c|c|c|c|}
\hline & \multirow{3}{*}{ Variabel } & \multicolumn{4}{|c|}{ Perilaku Anak Autis } & \multirow{3}{*}{ Total } & \multirow{3}{*}{ P Value } & \multirow{3}{*}{ OR } \\
\hline & & \multicolumn{2}{|c|}{ Hiperaktif } & \multicolumn{2}{|c|}{ Defisit } & & & \\
\hline & & $\mathrm{N}$ & $\%$ & $\mathrm{~N}$ & $\%$ & & & \\
\hline \multirow{8}{*}{$\begin{array}{l}\text { Suara } \\
\text { Cahaya }\end{array}$} & Suara Handphone & 11 & 91.7 & 1 & 8.3 & 12 & 0.048 & \\
\hline & Suara Lalu Lintas & 2 & 40 & 3 & 60 & 5 & & \\
\hline & Total & & & & & $(100 \%)$ & & \\
\hline & & 4 & 50 & 4 & 50 & 8 & & \\
\hline & Cahaya Matahari & 17 & 68 & 8 & 32 & 25 & & \\
\hline & & 15 & 83.3 & 3 & 16.7 & 18 & 0.031 & 12.500 \\
\hline & & 2 & 28.6 & 5 & 71.4 & 7 & & 97.647) \\
\hline & Total & 17 & 68 & 8 & 32 & & & \\
\hline
\end{tabular}

Sumber: Hasil olah data primer 2016

Berdasarkan hasil penelitian (Tabel.1) lingkungan fisik sangat berpengaruh terhadap perilaku anak autis, hasil dari lingkungan fisik suara diketahui dari 12 anak yang mendengarkan suara handphone terdapat 11 anak $(91,7 \%)$ yang berperilaku hiperaktif, 1 anak $(8,3 \%)$ berperilaku defisit. Hasil dari 5 anak yang mendengarkan suara hairdryer terdapat 2 anak $(40 \%)$ yang berperilaku hiperaktif, 3 anak (60\%) berperilaku defisit, dan hasil 8 anak yang mendengarkan suara lalu lintas terdapat 4 anak $(50 \%)$ yang berperilaku hiperaktif, 4 anak (50\%) berperilaku defisit. Hasil uji statistik dengan menggunakan uji chi square di peroleh nilai $p$ value dengan besar nilai $0,048<0,05$ yang berarti $\mathrm{P}<\alpha$ artinya terdapat pengaruh yang bermakna antara lingkungan fisik suara seperti suara handphone, suara hairdryer dan suara lalu lintas terhadap perilaku anak autis. Artinya dimana suara handphone, suara hairdryer dan suara lalu lintas yang berada disekelilingnya berpengaruh terhadap anak autis yang mengarah ke perilaku hiperaktif. Menurut Nawawi (2001), 
lingkungan fisik juga memberikan pengaruh terhadap perilaku anak, seperti suara yang tibatiba, suara keras terus-menerus, dan suara campuran seperti suara musik yang dapat merangsang perilaku anak autis. Perilaku anak autis memiliki sifat sangat berubah - ubah, baik dalam perilaku dan pendidikannya, peran keluarga dalam mendidik perilaku anak sangat berperan penting, orang tua harus melihat perilaku anak yang peka terhadap lingkungan sekitarnya seperti suara dan cahaya, orang tua harus bisa memberikan arahan dan motivasi bagi anak disekitarnya khususnya lingkungan fisik agar anak dapat merespon suara dan cahaya secara positif (Tony, 2007).

Hasil penelitian di lapangan sebagian dari orang tua banyak yang bekerja baik itu pekerjaan swasta maupun pegawai, orang tua sebagian banyak memberikan pengasuhan anak kepada pembantu atau supir antar jemput sekolah anak. Di sekolah anak autis selalu di berikan pendidikan dan ajaran baik itu suara dan cahaya, anak selalu diberikan ajaran mana itu suara musik atau suara panggilan yang menyebutkan namanya, anak autis sangat peka terhadap suara, baik itu suara musik, suara hewan, suara telephone dan suara sapaan saat dia memperkenalkan dirinya. Selain di sekolah orang tua harus memberikan dukungan emosional yang baik agar anak dapat berprilaku positif baik itu rangsangan suara dan cahaya yang ada disekitarnya misalnya orang tua dapat memberikan pengetahuan apa itu suara handphone, suara hewan dan suara lainnya agar anak peka terhadap suara, jika orang tua kurang memberikan dukungan emosional yang baik maka anak akan banyak mengalami perilaku hiperaktif dan tidak mau tau apapun yang ada desekitarnya. banyak orang tua yang memiliki kesibukan dan kurang memiliki waktu terhadap anak serta kebanyakan orang tua kurang memiliki rasa kesabaran dalam mengajari anak. Seharusnya orang tua memiliki sikap yang tegas agar anak peka terhadap suara maupun cahaya.

Berdasarkan hasil lingkungan fisik cahaya dari 18 anak respon terhadap cahaya diruangan gelap terdapat 15 anak $(83,3 \%)$ yang berperilaku hiperaktif, 3 anak $(16,7 \%)$ berperilaku defisit. dan hasil dari 7 anak respon terhadap cahaya matahari terdapat 2 anak $(28,6 \%)$ yang berprilaku hiperaktif, 5 anak $(71,4 \%)$ berprilaku defisit. Hasil uji statistik dengan menggunakan uji chi square di peroleh nilai $p$ value dengan besar nilai $0,031<0,05$ yang berarti $\mathrm{P}<\alpha$ artinya terdapat pengaruh yang bermakna antara lingkungan fisik cahaya seperti diruang gelap dan cahaya matahari terhadap prilaku anak autis. Hasil Odds Ratio $(O R=12,500 ; 95 \%$; Cl 1,600 - 97,647) dimana pengaruh cahaya mempunyai peluang 12,500 kali terhadap perilaku anak autis. Lingkungan fisik cahaya sangat berpengaruh terhadap anak autis, rangsangan cahaya yang berwana berbeda-beda sangat mempengaruhi perilaku anak autis, setiap anak ada yang tidak menyukai suatu warna misalnya warna merah atau warna kuning, jika anak tidak menyukai warna tersebut maka anak akan menjerit dan berlarilari Jika anak menyukai warna cahaya tersebut maka anak tersebut berprilaku defisit Nawawi (2001). Banyak anak menyukai cahaya seperti ruang gelap, prilaku anak bahkan sangat hiperaktif melompat - lompat kesana kemari dan berteriak sambil mondar mandir. Cahaya matahari juga memberikan stimulus rangsangan kepada anak, banyak anak yang menyukai cahaya matahari seperti saat anak bermain dilapangan dan berolahraga, saat anak dibawa ke cahaya matahari banyak perilaku anak yang bersifat hiperaktif.

Keluarga sangat berperan penting untuk mengatahui stimulus anak, orang tua tidak menyadari bahwa anak peka pada suatu warna, orang tua harus mengetahui tidak semua warna banyak disukai oleh anak, jika anak tidak menyukai warna tersebut maka anak akan berperilaku tidak mau tau, diam dan pergi. Orang tua harus memberikan stimulus gambaran warna cahaya yang disukai oleh anak. Selain disekolah banyak orang tua menyerahkan anak ke dalam terapi. Terapi juga memberikan pelatihan cahaya kepada anak agar anak bisa mengetahui berbagai warna cahaya baik itu gelap dan terang (Puspita, 2004).

Hasil penelitian dilapangan banyak anak autis yang sangat peka terhadap cahaya, baik itu cahaya diruang gelap perilaku anak autis sangat hiperaktif seperti melompat - lompat, berteriak dan kesana - kesini tidak mau duduk diam. Anak autis juga menyukai kepekaan terhadap salah satu cahaya warna baik itu cahaya gelap, terang, dan berwarna. Anak yang peka terhadap suatu warna akan bersifat hiperaktif, Orang tua harus menyadari bahwa lingkungan fisik disekitarnya seperti cahaya sangat memberikan pengaruh yang positif untuk anak.

Hasil penelitian ini sejalan dengan penelitian terdahulu (Fitri, 2014), yang berjudul pengaruh dukungan sosial keluarga dan lingkungan fisik terhadap perilaku anak autis. 
Hasil penelitian menujukan bahwa suara dan cahaya dapat mempengaruhi perilaku anak autis dengan nilai $\mathrm{p}<(0,044)$. Untuk variabel lingkungan sekolah terhadap perilaku anak autis (Tabel 2).

Tabel 2 Deskripsi variabel lingkungan sekolah terhadap perilaku anak autis

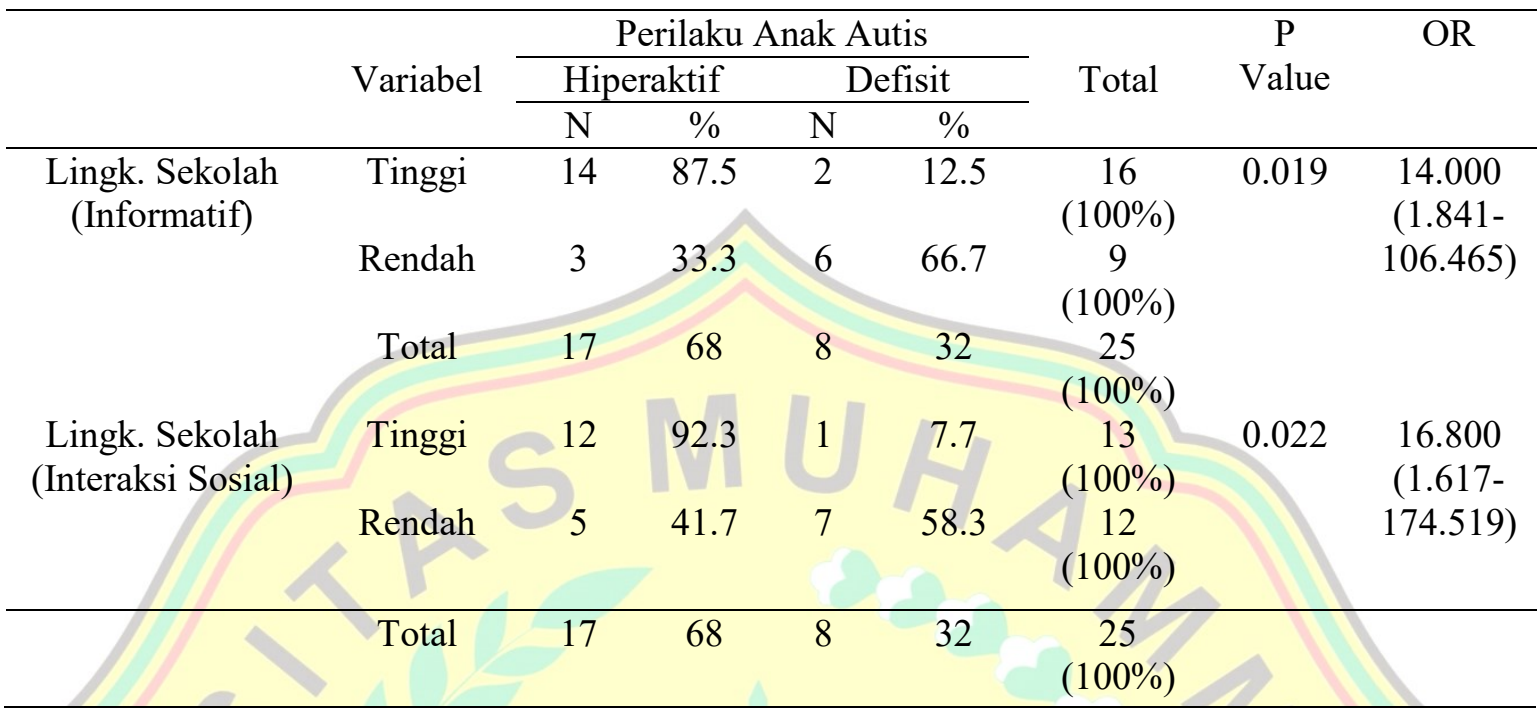

Sumber: Hasil olah data primer 2016

Hasil penelitian Berdasarkan (Tabel 2) lingkungan sekolah sangat berpengaruh terhadap perilaku anak autis hasil penelitian diketahui dari 16 anak dengan lingkungan sekolah (informatif) yang tinggi terdapat 14 anak $(87,5 \%)$ yang berperilaku hiperaktif, dan 2 anak $(12,5 \%)$ berperilaku defisit. Hasil dari 9 anak dengan lingkungan sekolah (informatif) yang rendah terdapat 3 anak $(33,3 \%)$ yang berperilaku hiperaktif, dan 6 anak (66,7\%) berperilaku defisit. Hasil uji statistik dengan menggunakan uji chi square di peroleh nilai $p$ value dengan besar nilai $0,019<0,05$ yang berarti $\mathrm{P}<\alpha$ artinya terdapat pengaruh yang bermakna antara lingkungan sekolah (informatif) terhadap perilaku anak autis. Hasil Odds Ratio $(O R=14,000 ; 95 \%$; C1 1,841 $106,465)$ dimana pengaruh lingkungan sekolah (informatif) dapat berpeluang 14,000 kali terhadap perilaku anak autis. Lingkungan sekolah merupakan rumah ke dua bagi anak, di dalam lingkungan sekolah anak diberikan motivasi serta pendidikan yang mengajarkan anak perilaku dan pengetahuan yang baik (Safaria, 2005).

Lingkungan sekolah anak dapat bergaul dan dapat belajar dengan kelompok bermain dengan teman sebayanya, pada umumnya anak autis memerlukan guru pendamping dengan kualifikasi yang jelas, lingkungan sekolah tempat belajar anak autis diberikan guru yang memberikan anak dukungan informatif yang baik. Anak diberikan dukungan informatif agar anak dapat berperilaku positif selain itu guru memberikan pelatihan, mengajari kedisiplinan dan materi pelajaran (Handojo, 2006).

Berdasarkan hasil penelitian dilapangan, guru sangat berperan penting dalam mendidik anak, dilingkungan sekolah anak selalu diberi dukungan informatif baik itu dalam memberikan materi belajar dan mendukung anak dalam perilaku yang positif, apapun kegiatan atau perilaku anak yang salah atau tidak baik guru selalu memberikan dukungan informatif yang baik kepada anak agar anak dapat berperilaku kearah yang lebih baik.

Berdasarkan hasil lingkungan sekolah (interaksi sosial) dari 13 anak terdapat 12 anak (92,3\%) berperilaku hiperaktif, dan 1 anak $(7,7 \%)$ berperilaku defisit. Hasil dari 12 anak dengan lingkungan sekolah (interaksi sosial) yang rendah terdapat 5 anak $(41,7 \%)$ yang berperilaku hiperaktif, dan 7 anak $(58,3 \%)$ berperilaku defisit. Hasil uji statistik dengan menggunakan uji chi square di peroleh nilai $p$ value dengan besar nilai $0,022<0,05$ yang berarti $\mathrm{P}<\alpha$ artinya terdapat pengaruh yang bermakna antara lingkungan sekolah (interaksi 
sosial) terhadap perilaku anak autis. Hasil Odds Ratio $(O R=16,800 ; 95 \%$; C1 1,617 - 174,519). Dimana pengaruh lingkungan sekolah (interaksi sosial) dapat berpeluang 16,800 kali terhadap perilaku anak autis. Dalam lingkungan sekolah interaksi sosial anak autis tidak mampu menjalin hubungan dengan baik, baik dengan menunjukkan suatu prilaku atau ciri khusus, seperti kontak mata sangat kurang, ekspresi wajah yang kurang hidup, gerak-gerik yang tidak tertuju, menangis tertawa tanpa sebab dan kurangnya hubungan sosial (Mariyana, 2010).

Lingkungan sekolah merupakan tempat kedua bermain anak baik dalam belajar maupun tempat berinteraksi dengan teman - teman sebayanya, di lingkungan sekolah guru sangatlah dibutuhkan untuk mendampingi anak, dalam perilaku anak yang hiperaktif guru harus memberikan pendidikan khusus bagi anak yang salah satunya cara berinteraksi dengan teman temanya ataupun dengan orang lain, perilaku anak autis sangat membutuhkan pendidikan yang sangat rutin, anak harus diberikan cara belajar berbicara dengan baik dan bisa memperkenalkan dirinya dengan orang lain. Orang tua yang memiliki anak dengan gangguan perkembangan autis, menginginkan anaknya mendapat pendidikan dan memiliki harapan agar anaknya dapat belajar bersosialisasi, berkomunikasi dan berinteraksi dengan lingkungan sekitarnya (Michalta, 2011).

Berdasarkan penelitian likungan sekolah (interaksi sosial), guru meberikan ajaran cara berinteraksi yang baik bagi anak, misalnya cara mengucapkan salam, memperkenalkan dirinya dan mampu berinteraksi sesama teman sekolahnya. meskipun perilaku yang hiperaktif anak mampu berinteraksi misalnya saat memperkenalkan dirinya dengan orang lain prilaku anak sambil ketawa - ketawa. semua anak autis yang berperilaku hiperaktif sangat membutuhkan bimbingan dan ajaran dari orang tua maupun lingkungan sekolahnya agar anak mengerti perilaku yang baik.

Untuk melihat pengaruh variabel lingkungan fisik terhadap perilaku anak autis (Tabel 3)

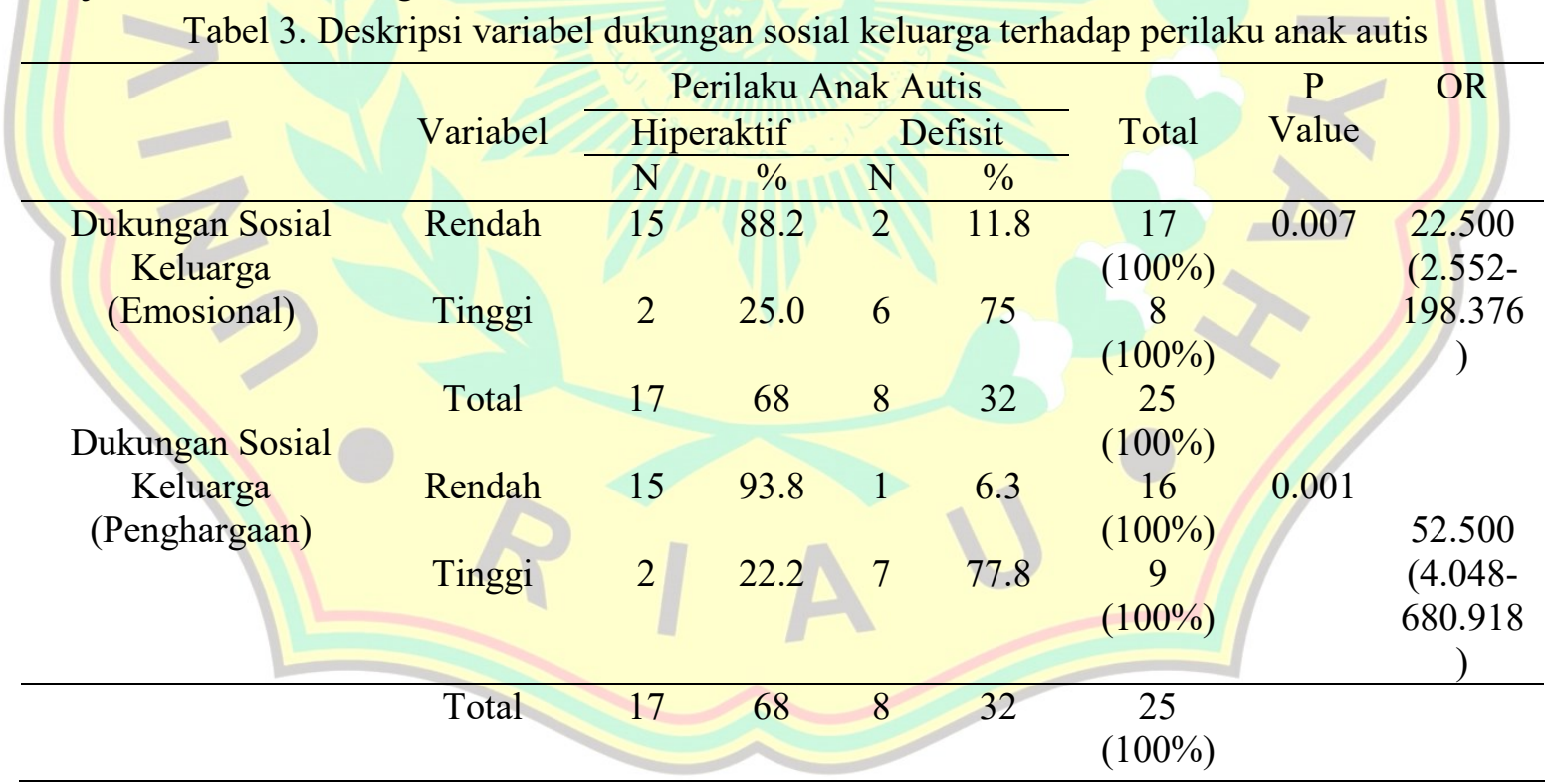

Sumber: Hasil olah data primer 2016

Hasil penelitian berdasarkan (Tabel 3) dukungan sosial keluarga sangat berpengaruh terhadap anak autis hasil penelitian diketahui dari 17 anak dengan dukungan sosial keluarga (emosional) yang rendah terdapat 15 anak (88,2\%) yang berperilaku hiperaktif, dan 2 anak $(11,8 \%)$ berperilaku defisit. Hasil dari 8 anak dengan dukungan sosial keluarga (emosional) yang tinggi terdapat 2 anak $(25,0 \%)$ yang berperilaku hiperaktif, dan 6 anak (75\%) berperilaku defisit. Hasil uji statistik dengan menggunakan uji chi square di peroleh nilai $p$ value dengan besar nilai $0,007<0,05$ yang berarti $\mathrm{P}<\alpha$ artinya terdapat pengaruh yang 
bermakna antara dukungan sosial keluarga (emosional) terhadap perilaku anak autis. Hasil Odds Ratio $(O R=22,500 ; 95 \%$; C1 2,552 198,376). Dimana pengaruh dukungan sosial keluarga (emosional) dapat berpeluang 22,500 kali terhadap perilaku anak autis. Orang tua sangat memiliki peranan penting bagi anak, anak sangat membutuhkan kasih sayang dan perhatian dari orang tua untuk membantu tumbuh kembang anak dan rasa nyaman terhadap anak, jika anak merasa mendapatkan dukungan, kasih sayang dan perhatian yang lebih dari orang tua maka anak merasa nyaman, bahagia dan merasa dicintai oleh lingkungan keluarga disekelilingnya (Smet, 1994).

Keluarga adalah dukungan utama yang harus memberikan perhatian lebih terhadap anak khususnya bagi orang tua, dukungan sosial keluarga sangat dibutuhkan dalam menjaga psikologis bagi anak yang mengalami autis. Apabila keluarga memberikan dukungan sosial yang baik atau lebih maka anak merasa mendapatkan perhatian, penghargaa dan kasih sayang yang lebih maka anak merasa nyaman dan lebih terarah dalam berperilaku ke arah normal atau defisit. Dampak dari sikap orang tua yang tidak dapat menerima anaknya memiliki gangguan autis sangat lah tidak baik, orang tua bahkan kurang memiliki perhatian karena tidak dapat mengerti tentang perilaku anak sehingga anak dapat berprilaku yang tidak diinginkan (Marijani, 2003).

Berdasarkan penelitian dukungan sosial keluarga (emosional), didapatkan hasil dukungan sosial keluarga (emosional) yang rendah sehingga menyebabkan perilaku anak mengarah ke hiperaktif, banyaknya orang tua yang bekerja membuat anak kurang merasa tidak diperhatikan dan merasa kurang mendapatkan kasih sayang. Berdasarkan umur orang tua banyak dalam masa produktif dan rata-rata memiliki pekerjaan di luar rumah seharian. Sehingga orang tua kurang memiliki waktu, perhatian dan perkembangan anak disekolah maupun dirumah.

Perilaku anak autis sangat membutuhkan perhatian oleh orang tua, karena semakin tinggi perhatian yang akan diberikan kepada anak maka prilaku anak akan mengarah kedefisit atau normal. Bila orang tua sibuk bekerja dan kurang meberikan anak perhatian atau kasih sayang yang lebih maka anak akan berperilaku ke hiperaktif karena kurangnya arahan dan ajaran motivasi dari orang tua atau sekelilingnya. Berdasarkan hasil penelitian yang dilakukan Rahmayanti (2007), yang berjudul penerimaan diri orangtua terhadap anak autism dan peranannya dalam terapi autisme yang hasilnya penerimaan diri orang tua terhadap anak autis dipengaruhi oleh faktor dukungan dari keluarga besar, kemampuan keuangan keluarga, pendidikan, usia, dukungan lingkungan masyarakat dan agama.

Berdasarkan hasil dari 16 anak dengan dukungan sosial keluarga (penghargaan) yang rendah terdapat 15 anak $(93,8 \%)$ berperilaku hiperaktif, dan 1 anak $(6,3 \%)$ berperilaku defisit. Hasil dari 9 anak dengan dukungan sosial keluarga (penghargaan) yang tinggi terdapat 2 anak $(22,2 \%)$ yang berperilaku hiperaktif, dan 7 anak (77,8\%) berperilaku defisit. Hasil uji statistik dengan menggunakan uji chi square di peroleh nilai $p$ value dengan besar nilai $0,001<0,05$ yang berarti $\mathrm{P}<\alpha$ artinya terdapat pengaruh yang bermakna antara dukungan sosial keluarga (penghargaan) terhadap perilaku anak autis. Hasil Odds Ratio $(O R=52,500 ; 95 \% ; C 14,048-680,918)$ dimana pengaruh dukungan sosial keluarga (penghargaan) dapat berpeluang 52,500 kali terhadap perilaku anak autis. Dukungan sosial keluarga (penghargaan) sangat memiliki peranan penting terhadap anak autis menurut Permatasari (2009), sikap dukungan penghargaan orang tua tidak hanya diberikan untuk anak normal saja melainkan sangat dibutuhkan oleh anak yang tidak normal khususnya untuk anak yang berperilaku autis, anak autis akan lebih merasakan nyaman bila orang tua akan memberikan dukungan penghargaan seperti rasa menghargai diri sendiri, memiliki sikap yang percaya diri, dan memiliki sikap yang baik.

Berdasarkan hasil penelitian dukungan penghargaan orang tua terhadap anak autis juga mempengaruhi karakteristik perilaku orang tua, 
berdasarkan usia yang dapat mempengaruhi tingkat kematengan berfikir pengalaman ini dapat dipengaruhi dalam kehidupan sehari-hari, pengalaman orang tua dalam mengasuh perilaku anak autis sehari-hari dapat memberi motivasi dalam berfikir serta memberikan dukungan penghargaan terhadap perilaku anak autis. Sebagian dari orang tua dapat dengan iklas menerima segala kekurangan anak dan anak autis kebanyakan satu-satunya anak dalam keluarga sehingga orang tua dapat menghargai dan menerima anak. Orang tua yang tidak dapat menerima kekurangan anak dan tidak dapat menghargai anak akan dapat menyebabkan perilaku anak semakin hiperaktif karena anak kurang mendapatkan dukungan seperti kasih sayang, emosional, dan penghargaan (Sarasvati, 2004).

Hasil penelitian ini sejalan dengan penelitian Fitri (2014), yang berjudul pengaruh dukungan sosial keluarga dan lingkungan fisik terhadap perilaku anak autis. Hasil penelitian menunjukan bahwa dukungan sosial keluarga (penghargaan) yang rendah dapat mempengaruhi perilaku anak autis dengan nilai $\mathrm{p}<0,049,(\mathrm{OR})=12,678$.

\section{KESIMPULAN}

a. Lingkungan fisik (suara dan cahaya) memberikan pengaruh yang bermakna terhadap perilaku anak autis seperti suara handphone, suara hairdryer dan suara lalu lintas. Artinya dimana suara handphone, suara hairdryer dan suara lalu lintas yang berada disekelilingnya berpengaruh terhadap anak autis yang mengarah ke perilaku hiperaktif seperti berlari - lari, mondar mandir tanpa arah, melompat lompat dan menjerit. Adapun anak yang berprilaku defisit karena anak merasa gelisah, menangis dan kurang nyaman. Lingkungan fisik cahaya diruang gelap dan cahaya matahari memberikan pengaruh terhadap perilaku anak autis, sebagian besar anak autis cenderung berperilaku hiperaktif saat berada diruangan yang gelap karena anak ada yang merasa nyaman dengan melompat - lompat dan berlari mondar - mandir, anak yang berprilaku defisit diam dan menangis saat berada diruang gelap. Cahaya matahari memberikan pengaruh terhadap perilaku anak autis. Anak yang hiperaktif merasa nyaman di tempat cahaya yang terang dan anak yang defisit merasa gelisah dan tidak nyaman.

b. Lingkungan sekolah (informatif dan interaksi sosial) memberikan pengaruh yang bermakna terhadap perilaku anak autis, Artinya semakin sering guru sekolah memberikan dukungan dan arahan informatif kepada anak, maka anak semakin dapat berperilaku hiperaktif dengan cara belajar disekolah. dan adanya pengaruh yang bermakna antara lingkungan sekolah (interaksi sosial) guru sekolah meberikan interaksi sosial yang baik terhadap anak di lingkungan sekolah sehingga anak cenderung berperilaku hiperaktif dalam belajar maupun berinteraksi dilingkungan sekolah maupun diluar sekolah.

c. Dukungan sosial keluarga (emosional dan penghargaan) memberikan pengaruh yang bermakna terhadap perilaku anak autis. Artinya dukungan emosional keluarga yang rendah akan membuat anak lebih cenderung berperilaku hiperaktif, perhatian orang tua atau keluarga sangat dibutuhkan oleh anak seperti pelukan, kasih sayang, belaian dapat membuat anak merasa senang dan dukungan penghargaan keluarga atau orang tua yang rendah terhadap anak akan mengakibatkan anak lebih cenderung ke perilaku hiperaktif sedangkan anak yang berperilaku defisit hanya sebagian kecil dukungan sosial keluarganya yang tinggi.

\section{DAFTAR PUSTAKA}

Arifin, Z. 2009. Evaluasi Pembelajaran. PT. Remaja Rosdakarya. Bandung.

Baharuddin, D. 2012. Teori Belajar dan Pembelajaran. Ar-Ruzz Media. Jogjakarta. 
Carman, L.C. 2007. Kesehatan jiwa dan pskiatri: pedoman klinis perawat (pschiatric and mental health care: nurse's clinical guide. EGC. Jakarta.

Chaplin, C.P. 2000. Kamus lengkap psikologi. Alih bahasa: Kartini Kartono Rajawali Press. Jakarta.

Danuatmaja, B. 2003. Terapi autis di rumah Puspa Swara Jakarta.

Delphie, B. 2009. Pendidikan Anak Autis. KTSP. Sleman.

Depdiknas. 2002. Pedoman pelayanan pendidikan bagi anak autistik.
Depdiknas. Jakarta.

Fitri, A. 2013. Pengaruh Dukungan Sosial Keluarga dan Lingkungan Fisik Terhadap Perilaku Anak Autis di Kota Pekanbaru. Tesis. UR: Pekanbaru.

Gunadi, T. 2011. Seminar national series III: deteksi dini, terapi dan cara mengembangkan kecerdasan anak autisme 2011. Diperoleh tanggal 15 Juni 2015 dari www. Klinikanakyamet.Multiply.com/journal.

Hadis, A. 2006. Pendidikan anak berkebutuhan khusus autistik. Alfabeta. Bandung.

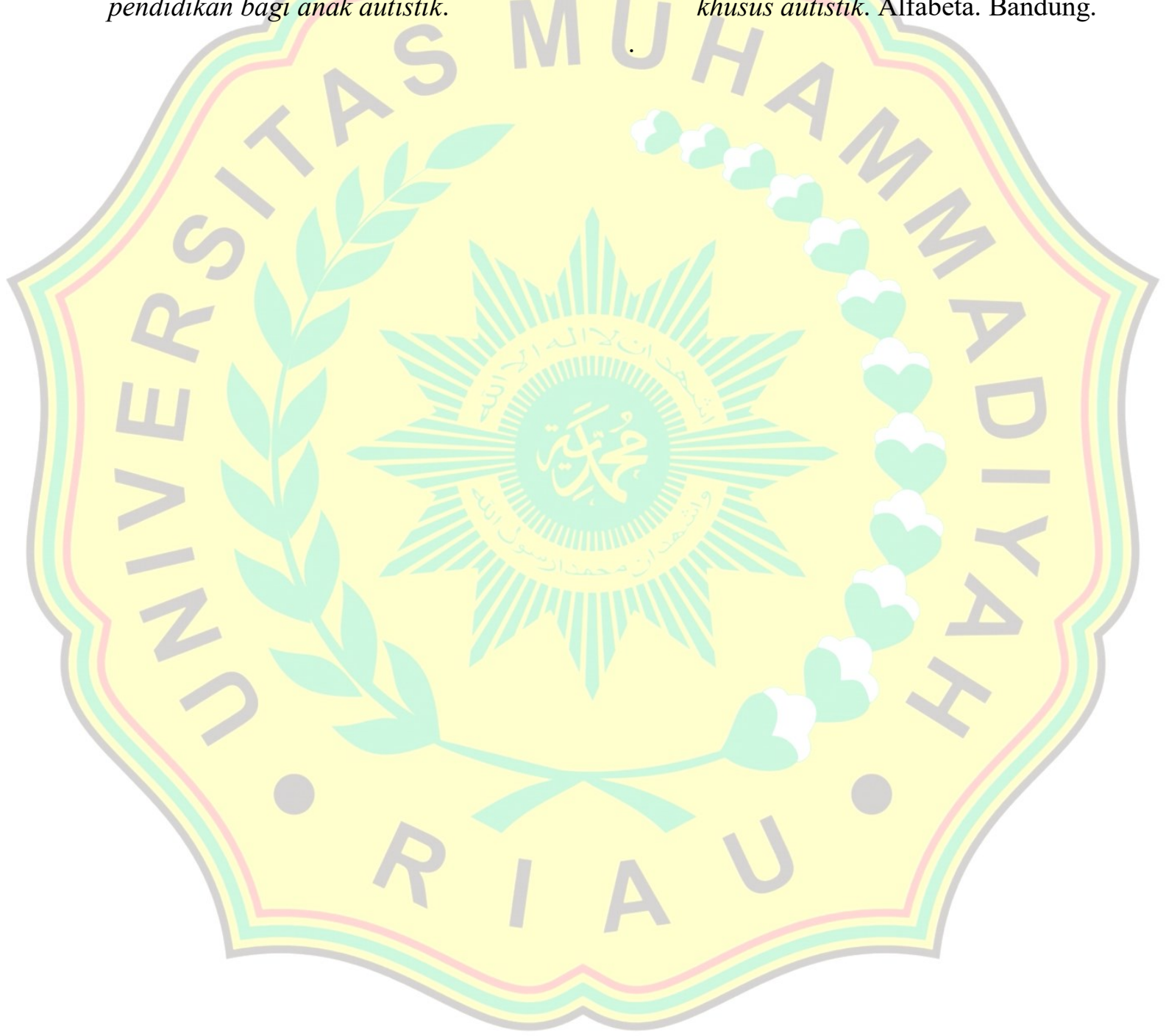

